International Journal of Linguistics, Literature and Translation (IJLLT)

ISSN: 2617-0299 (Online); ISSN: 2708-0099 (Print)

DOI: $10.32996 / \mathrm{ijllt}$

Website: https://al-kindipublisher.com/index.php/ijllt

IJLLT

\title{
The Implementation of Lectora Inspire Application as Interactive Learning Media on English Writing Skill for Students at SMP N 35 Medan
}

Sumarsih*1, Safrida Lubis ${ }^{2}$, Asrita Sari ${ }^{3}$ and Edi Rahmadani ${ }^{4}$

${ }^{1234}$ English and Literature Department, Universitas Negeri Medan, Medan, Indonesia

Corresponding Author: Sumarsih, E-mail: prof.sumarsih@gmail.com

ARTICLE INFORMATION

Received: September 08, 2020

Accepted: October 17, 2020

Volume: 3

Issue: 10

DOI: $10.32996 /$ ijllt.2020.3.10.9

\section{KEYWORDS}

Lectora Inspire, Writing, Genres, Research and Development

\section{ABSTRACT}

Technology development demands the existence of innovation in education sector. Therefore, technology use has to be optimized well. The study aimed at developing Lectora Inspire application as interactive learning media on English writing skill for students and to know the application effectiveness toward students at SMP N 35 Medan. Research and Development was conducted in the study. There were some steps conducted such as, preliminary, developing, and evaluating. The subject of the study was 30 students of seventh, eighth, and ninth grade students at SMP N 35 Medan chosen randomly. The techniques of collecting data were documentation, interview and questionnaire. Furthermore, the data were analyzed by using descriptive qualitative and quantitative analysis. The result of the study showed that Lectora Inspire application was an appropriate interactive learning media on writing for students at SMP N 35 Medan. Since the interactive learning media had been validated by some experts and got the average percentage $95 \%$ categorized excellent. In addition, the result of the study showed that there was the students' improvement on writing skill related to genres which meant that the media was effective media in learning writing at SMP N 35 Medan.

\section{Introduction}

Nowadays, technology development is able to influence all aspects of life including education. The technology development is a sign of the existence of the industrial revolution 4.0. Then, in 21st century, technology has an important role in advancing education itself. The existence of the technological development demands more innovation as an absolute thing to do, because without innovation there will be backwardness in the world of education and then it will impact on other life elements such as politics, economy, social and others. Education cannot be separated from the learning. Learning is a series of activities that are deliberately created with the intention of facilitating the students' learning process.

In the field of English education, for instance, the teachers have to understand and able to use technology to help the students in the teaching-learning process. Furthermore, the innovation of technology information and communication will support the achievement of an effective teaching-learning process.

Educational technology experts argued that the main role of educational technology is to help increase overall efficiency in the teaching and learning process. The application of educational technology is also expected to make teaching and learning processes more efficient, effective and provide positive added value.

Based on MENRISTEKDIKTI related to the impact of industrial revolution 4.0, teachers and lecturers have to adaptable to the digitalization system. Cambridge International's research through the Global Education Census 2018 had shown that Indonesian students are very familiar with technology, not only in interacting on social media but also for learning needs.

The results of the study stated that Indonesian students were in the highest warning globally of IT / Computer users in the schools by $40 \%$. More than two-thirds as much as $67 \%$ use mobile phone in the classroom, and $81 \%$ use for doing homework.

K C AL-KINDI CENTER

R D FOR RESEARCH AND $\mathbf{R} \mathbf{D}$ DEVELOPMENT

Your gateway to world-class research
Published by Al-KindiCenter for Research and Development. Copyright (c) the author(s). This is an open access article under CC BY license (https://creativecommons.org/licenses/by/4.0/) 
The current situation can be maximized in positive way by upholding student-centered learning relating to 2013 curriculum currently which also focus toward student-centered learning itself, as stated of Minister of Education and Culture Regulation (PERMENDIKBUD) No. 81A about the implementation of 2013 Curriculum.

Furthermore, in language learning there are four skills that must be mastered by students namely, listening, speaking, reading, and writing. Writing is the ability that is owned to express ideas and feelings. Dalman (2004) stated that writing is an activity of communicating in the form of delivering messages (information) in writing to other parties using written language as a tool or medium.

In addition, students are required to master writing skill in accordance with the topics being taught. One of them is "genre" text. Ardiyono (2007) stated that there are some types of text into several types such as procedural, narrative, recount, explanation, exposition, discussion, review, anecdote, spoof, news item, report, and descriptive text. Based on the 2013 curriculum that has been implemented in the schools, students are required to master the genre by using language skills. One of them is writing by comparing, capturing, and compiling the story of the text. Based on the 2013 curriculum, the learning process must be student-centered learning.

However, the reality found that the students at SMP N 35 Medan had not been able to master English, especially in writing based on genre texts. It was proven by the students' scores which were under minimal mastery criteria namely 75 . Since the students did not understand how to write a paragraph, organize the paragraphs into a text that had been taught. In addition, these students also had difficulty understanding English grammar because it was considered difficult. Therefore, the students felt bored and were not interested in learning to write English. Thus, learning objectives were not able to be achieved in the class.

Based on preliminary data found, it was known that there are four English teachers at SMP N 35 Medan. The teacher taught using conventional methods where the teacher only explained and the students did the tasks given according to the topics taught even though the school already had some tools to support learning such as projector and laptops. However, the use of these media is not done optimally to create interactive learning. This shows that students were inactive and not in accordance with the 2013 curriculum which was student-centered. In addition, the learning process also did not support the technology use as an important element in improving education quality. Therefore, an interactive media that required the students to be active was needed in order to improve the students' motivation in mastering genre-based writing skill in English subject. Naz and Akbar (in Omenege 2016) stated that media was a message transmission or delivery, and in a learning perspective, media was used to convey content to recipients and to achieve effective instruction.

Therefore, the teachers are required to create innovative and interesting learning. One of them is creating interactive learning media using the Lectora Inspire application. There are many softwares that support interactive learning media, but the Lectora Inspire application is an authoring tool that can make it easier for teachers to create and design interactive learning multimedia that is in accordance with English teaching materials (Mudinillah, 2019). The application has quite complete features, from inserting images, inserting videos, flash animation to inserting educational games. Apart from that, the uniqueness and completeness of other Lectora Inspire lies in the ability to insert practice questions complete with feedback that shows right or wrong answers, and scores that can be known directly. This application also has several menus which are easy for teachers to create interactive learning media.

Furthermore, the use of Lectora Inspire as an interactive learning media had been known to improve students' learning abilities. It related to a research conducted by Nur Rahmi Akbarini, Wiedy Murtini and Andre N Rahmanto (2018), which states that Lectora Inspire could improve students' learning outcome effectively. The students responded to the Lectora Inspire use as an interactive media and increased their motivation in learning as evidenced by an increase in the mean score from 68 in the pre-test to 81.53 in the post-test. There are several benefits of Lectora Inspire use as an interactive learning media, namely (1) Teachers can create and present teaching materials without programming; (2) The teacher can conduct tests on the teaching material given, in various forms of tests such as multiple choice, true / false, matching, drag and drop, fill in the blank, and hot spot.; (3) Teachers / students can access the teaching / testing materials needed both offline and online; (4) It is able to use text, sound, video, animation in one unit; and (5) It is able to visualize abstract material.

Therefore, the research was conducted to develop Lectora Inspire application as interactive learning media on writing students at SMP N 35 Medan and to know the effect of Lectora Inspire implementation toward the students' writing skill. 


\section{Literature Review \\ 2.1 Writing}

Tarigan (1982, p. 3) stated that writing can be defined as a productive and expensive activity. Writing skill cannot be mastered automatically, but it needs a lot of practice to be able to use the writing components and to know writing purpose itself. Furthermore, writing is an ability to make a form of words that in general, may have a higher truth value that the fact that it has set it down. It means that the writing product should be truly accepted by the readers (Randal, 2004, p. 160). Besides, writing must consist of meaningful values in order that the readers can get the benefit of writing.

Hyland (2000:172) stated that writing is a process to develop our ideas to think explicitly about how to organize and express the thought, feeling, and ideas in way of compatible with wished reader's expectations. In addition, writing is one kind of expression in the language which is created by a particular symbol set, having conventional values in representing in wording of particular language which drawn up visually. Furthermore, Brown (2000) stated that writing needs a thinking process, drafting, and revising that necessity specializing the skill and producing writing well. Then, it cannot be achieved in a short time, but needs some stages of writing process.

Besides, Harmer (2007:86) stated that writing is a process that is often heavily influenced by the constraints of genre, then these elements have to exist in writing learning activities. In this case, writing activities can exist in the classroom.

Based on the explanation above, it can be concluded that writing skill is a ability in expressing the ideas, thought, and felling in form of words so that the readers can know and understand the message given. There are some stages of writing such as thinking process, drafting, and revising. In writing, it is necessary to pay attention toward some genres in English, because writing is inherent with genres.

Furthermore, Tomskin (2004) stated that there are 5 stages of the writing process namely prewriting, drafting, revising, editing, and publishing.

\subsection{Teaching Writing}

Teaching writing skill differs from teaching the other language skills because the competence of producing and comprehending written skill is different with oral language skill. Zemach and Rumisek (in Nurmalasari, 2013) stated that there are six steps of the writing process to produce good writing namely, choosing a topic, gathering ideas, organizing, writing, and reviewing structure and content, and the last rewriting.

\subsection{Genre Texts}

Ardiyono (2007) stated that there are some types of the text such as, (1) procedural, it is a text to describe how something is accomplished done through a sequence of series or steps; (2) narrative, it is a text to amuse, entertain the reader about the vicurious experiences in different ways; (3) recount, it is a text to retell something that happened in the past and to tell a series of past event; (4) explanation, it is a text to explain process involved in the formation/working in natural and cultural phenomena; (5) exposition, it is divided into analytical exposition (to persuade the reader that the idea is important matter) and hortatory exposition (to persuade the reader to have the addressee do something or act in certain way. Or should or should not be the chase); (6) discussion, it is a text to present information and opinions about issues in more one side of an issue ('For/Pros' and 'Against/Cons'); (7) review, it is a text to critique or evaluate an art work or event for a public audience; (8) anecdote, it is a text to retell an unusual or amusing incident, not only to make people laughter but also to reveal the truth its self; (9) spoof, it is a text to tell an event with a humorous twist and entertain the readers; (10) news item, it is a text to inform the readers about events of the day which are considered news worthy or important; (11) report, it is a text to describe the way thing are in general inferences / to report something; and (12) descriptive text, it is a text to describe and reveal a particular person, place or thing in detail.

\subsection{Interactive Learning Multimedia}

Interactive learning multimedia is a teaching delivery system that presents recorded video material with computer control to the audience (students) who can not only hear and see the video and sound but also provide active responses and those responses that determine the speed and sequence of the presentation (Seels and Glasgow in Arsyad, 2002: 36). The intended interactive learning media is in the form of Compact-Disk (CD). The media is called Interactive Multimedia CD. It is called as multimedia because the media has audio-visual elements (including animation). It is an interactive media because it is designed to actively involve the students' response. Therefore, this kind of media can be classified as e-Learning teaching material. Swajati (2005) stated that e-Learning is an attempt to transform the teaching and learning process that exists in the 
schools into digital form. There are some advantages of interactive learning multimedia such as, (1) Enlarging objects that are very small and not visible;(2) Minimizing very large objects, which may not be presented at school; (3) Presenting objects or events that are complex, complex, and take place sooner or later; (4) Presenting an object or a distant event, through multimedia, the teacher can present objects such as planets, moon, stars, and snow into the classroom; and (5) Presenting the dangerous objects or events. Thus, the teacher can present dangerous events such as bomb blasts, rocket launches, volcanic eruptions, fires, wild animals, poisons, and others to attract students' interest.

\subsection{Lectora Inspire}

Lectora Inspire is an authoring tool software to develop E-Learning content which is developed by Triviants Corporation which was founded by Timothy D. Loudermilk in Cincinnati, Ohio, USA in 1999 (Mas'ud , 2014). Lectora can be used to create online course training, evaluation, presentation, as well as to convert presentation in Microsoft PowerPoint into E-Learning content. It is really easy to use in developing interactive learning media content. Furthermore, the contents of media developed by Lectora Inspire software can be published into several forms such as HTML, Single File Executable, CD-ROMS, and E-Learning standards such as SCROM and AICC. Not only that, but the software is also compatible with the Learning Management System basis (LMS).

Lectora enables the users as the teachers to create different kind of tests and surveys by using the combination of true and false, drag and drop, essay, and in the form of short answer. Users can center the variable of knowledge object by using the Action Palette to make a scenario of branching learning to study adaptively. Lectora has a set of automatic tools, including title Wizard, Spell check, and registry the menu reference and a new reference builder menu automatically.

The characteristics of Lectora Inspire that are distinguished relating to the other such as, (1) it provides a template that can be applied to compile learning material, (2) there are images, animations, animated characters that can be used directly, (3) Lectora is faster than web applications base because it does not depend on connection or network, (4) there is supporting software that is automatically installed when installing Lectora Inspire applications, such as flypaper, Camtasia, or Snagit, (5) it can be used to combine flash, video, images or screen capture, (6) there are some material menus of the Lectora program such as, chapters, sections, pages, then insert various facilities in Lectora (insert the image, insert audio, animation, etc.). In addition, it also has some icons to create questions or quizzes, and publish the interactive media itself (Febrianto, 2013).

Furthermore, there are several advantages of Lectora Inspire use such as, (a) The learning system is more interactive; (b) It is able to combine images, audio, video, and animation in one unit; (c) It is able to visualize abstract material; (d) it is relatively easy and flexible storage media; (e) It is able to carry large objects in the class; (f) It can show objects that cannot be reached by the naked eye.

However, there are also some disadvantages of Lectora Inspire namely, (a) it depends on high electric current; (b) it must be supported the media (computers and LCD) which are quite expensive; (c) there is lack of abilities in creating presentation media particularly the teachers; and (d) the media depends on the presenter of the material (the presenter must master the material).

Therefore, the Lectora media use is very appropriate in mastering writing skill because it is not only easy to be used but also interactive and contains material including images, animation, video, and sound. Then, it makes the students understand the material and make students nget bored easily. Besides that, in the Lectora media, there is also a test that can be directly done and the grade of tests can be immediately known if the student has finished working on all the questions. The test also consists various test such as, multiple-choice, right and wrong, matching, brief description, and essay. The test existence in the Lectora media helped the students in measuring learning activities particularly toward writing skill. Then, it could improve students' motivation in mastering writing skill especially in genres writing activities where the scores were still under the minimal mastery criteria (KKM).

\section{Research Method}

The study had been conducted by using Research and Development (R\&D). The study aimed at developing Lectora Inspire application as interactive learning media on Writing for students and to know the application effectiveness toward students at SMP N 35 Medan. As noted by Gall and Borg (2003:570), the R \& D study is a research process used to develop and validate educational products such as syllabus, materials, educational modules, media, etc. It implied that by using this type of study, the researcher researched to collect relevant data for designing an educational product. After the educational product was 
designed, the researcher validated its quality and feasibility based on validators' judgments. Then it was implemented to know the effect of media toward students' learning in writing.

The subject of the study was 30 students of seventh, eighth, and ninth grade students at SMP N 35 Medan chosen randomly. The techniques of collecting data were documentation, interview and questionnaire. Furthermore, the data were analyzed by using descriptive qualitative and quantitative analysis.

\section{Results and discussion}

Based on data found, it was known that there were several difficulties faced by students in achieving the objectives of the teaching and learning process itself due to manual learning media. The learning media needed at SMP Negeri 35 Medan was a medium which could attract the students' attention in writing genre.

On the other hand, teachers also had difficulty getting students to understand the material being taught due to the lack of learning media and lack of knowledge in developing learning media. From the interviews conducted, researchers could identify that teachers also needed learning media which could make the learning process more effective and efficient. Besides, learning media had to be related to daily life and attract students' attention in mastering writing skill. Furthermore, based on questionnaire results given to the students, it was known that the students wanted the combination of interesting, motivates in learning, and color combination in interactive learning media.

Therefore, Lectora Inspire was developed to improve students' writing at SMP N 35 Medan. The interactive learning multimedia was developed by the researcher by doing several steps. The steps consisted of preparing the material, designing the story board, choosing the layout, background, sound, video, and animations. The interactive learning multimedia consisted of the text, pictures, video, back sound, monologue, grammar zone, activities, complement consisted of vocabularies, reflection, and summary, evaluation test and also the explanation of the materials based on students and teacher's needs.

In order to implement the 2013 curriculum that applied scientific approach, Sani (2015) stated that scientific approach can be done in the following steps; a) observing, b) questioning, c) experimenting, d) associating, and e) communicating.

In the teaching learning process, applied based on scientific approach, the teacher started the class by greeting the students, checking the students' attendance and then doing pray together. After that, the teacher gave the clue about what the topic would learn. The interactive learning multimedia showed the material relating to genre text to stimulate students about material. The material included explanation, examples and also grammar in writing genre itself. The scientific approach steps of recount text as one of genres could be defined as follows.

a. Observing

In this step teacher showed videos about simple stories relating to personal experiences in the past and then asked to student to pay attention. But before that, teacher asked to students to find out past verbs and change them to the infinitive verb. After student finished of their task, teacher stimulated to ask questions about the video.

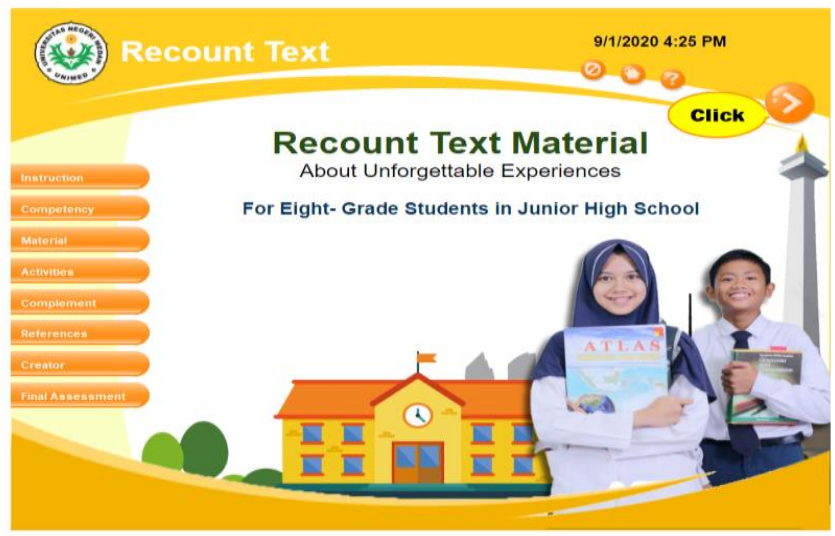

Figure 4.1. The Front View of Interactive Learning Media 
b. Questioning

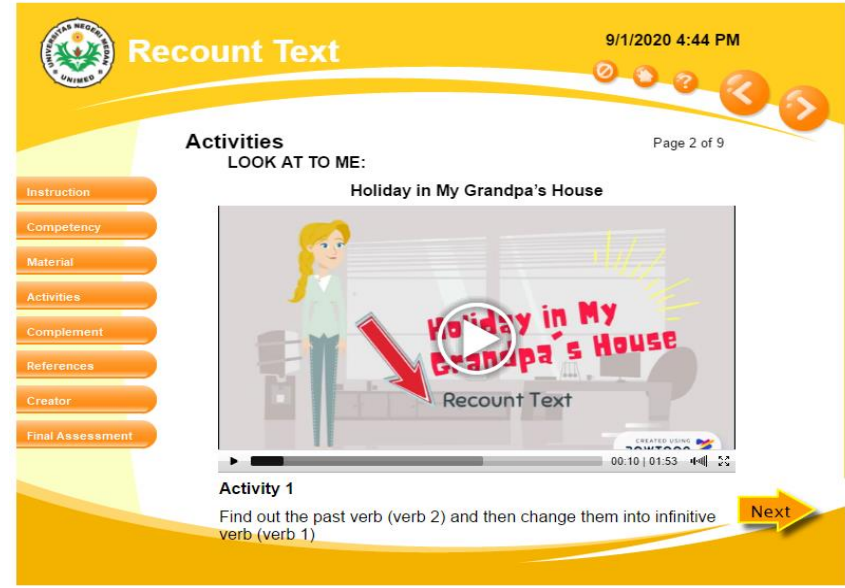

Figure 4.2. Personal Recount Text Video and Its Activity

In this step, teacher stimulated the students to ask the question relating to the video.

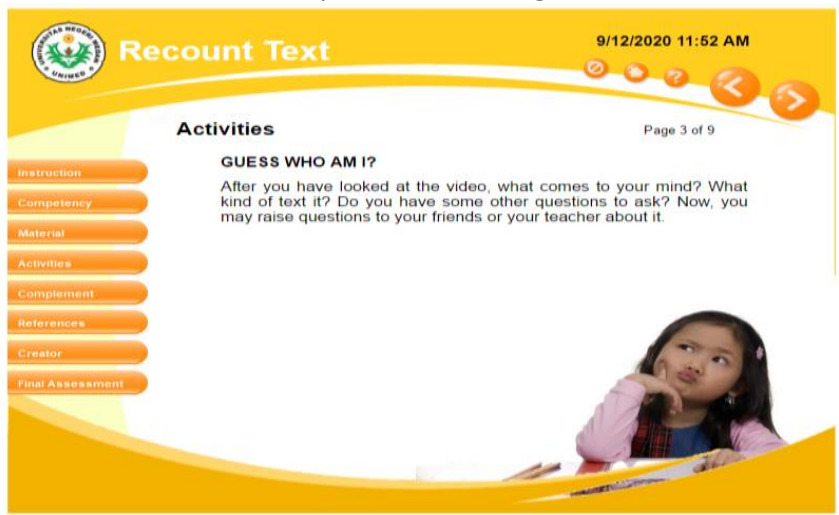

c. Experimenting

Figure 4.3. Stimulating Students to Ask the Questions about the Video

In this step, the teacher divided students into groups. Each group consisted of 2-4 people and displayed recount text the material along with examples. Then, the teacher also stimulated students to ask the question about the material. And then there was the grammar zone and task to be done.

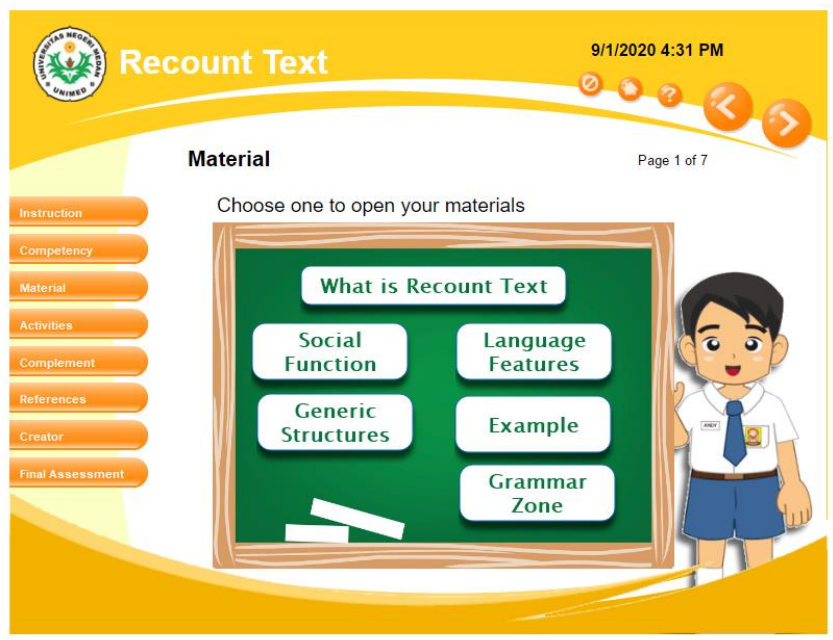

Figure 4.4. Experimenting Material 


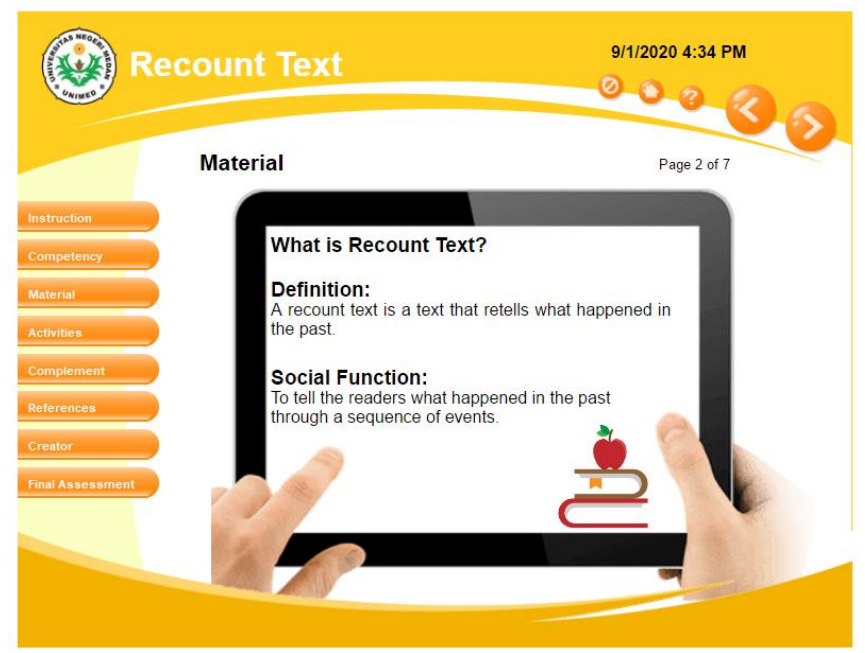

Figure 4.5. Recount Text Material

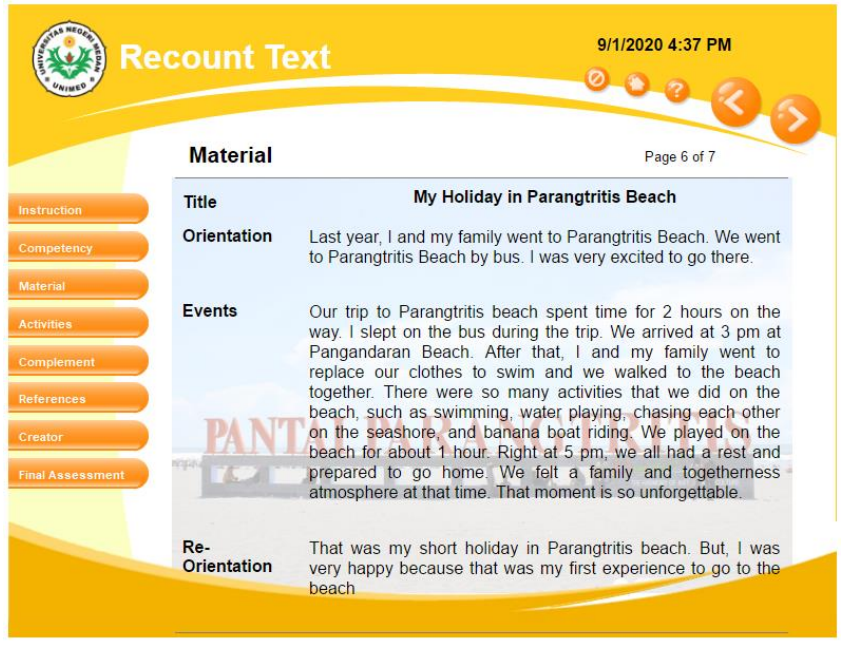

Figure 4.6. The Example of Recount Text

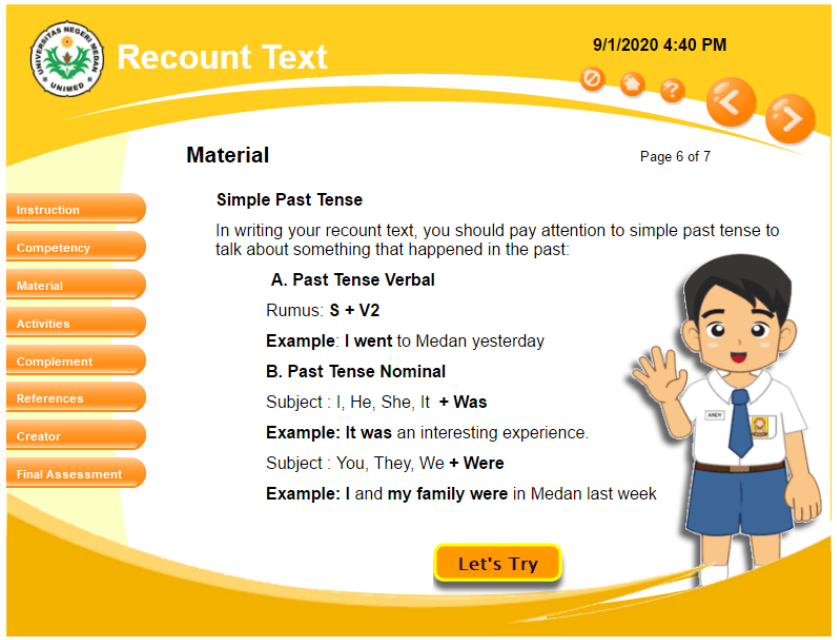

Figure 4.7.Language Features of Recount Text 
d. Associating

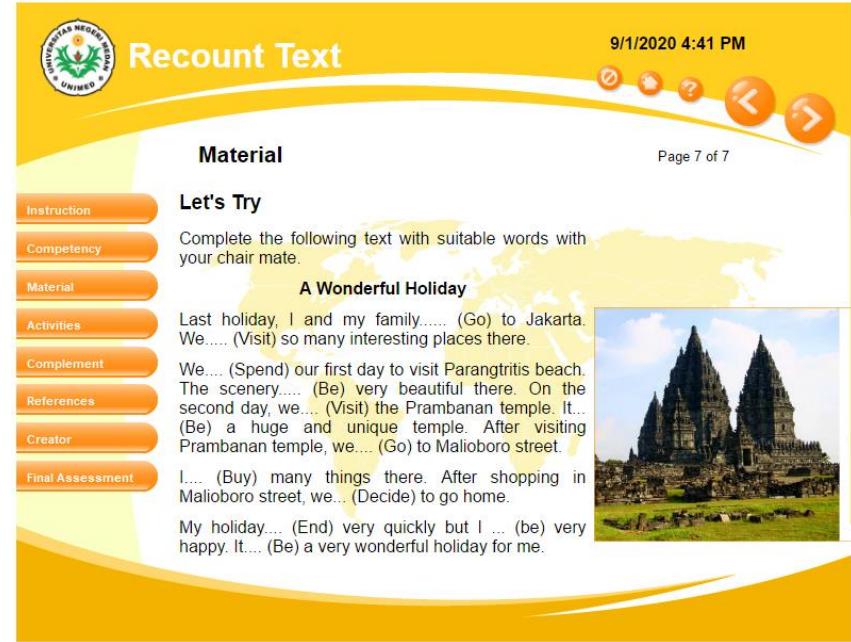

Figure 4.8. Language Features Task

After the teacher displayed the material and the example of recount text, the teacher asked to students in groups to answer questions relating to recount text in activities menu.

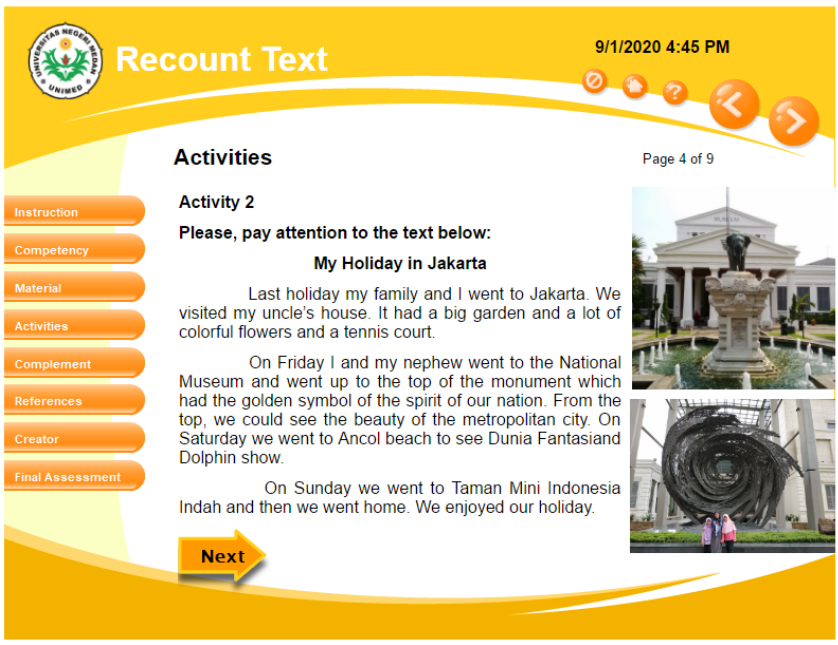

Figure 4.9. The Example of Recount Text

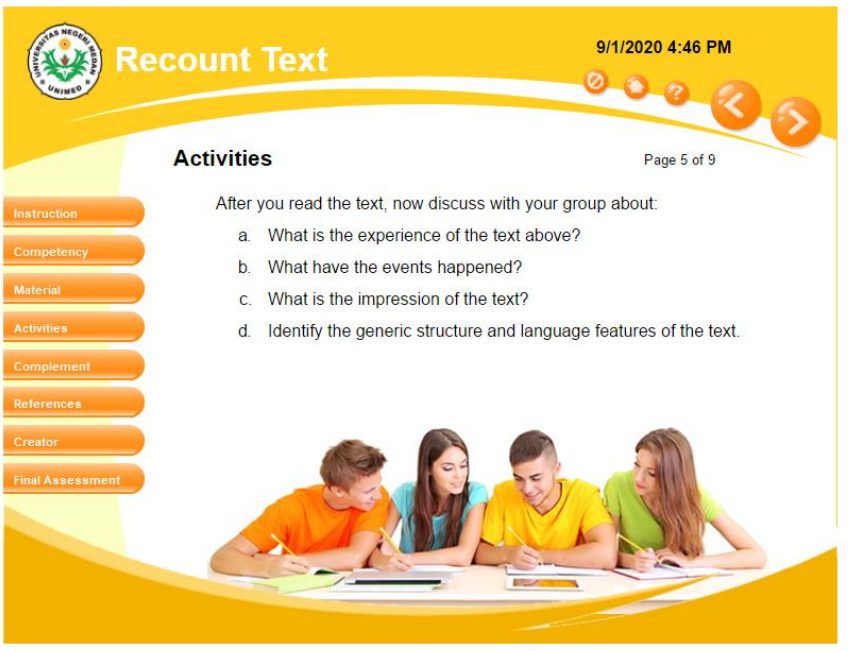

Figure 4.10. Task Relating to the Previous Text 


\section{e. Communicating}

Furthermore, after the students finished doing their task, they were asked to write personal recount text about unforgettable experiences. Then, the students had to exchange their texts to the other students in order that all the students could check their friends' personal recount text based on the generic structure and language features. Those results would be displayed on the wall provided by the teacher in the class.

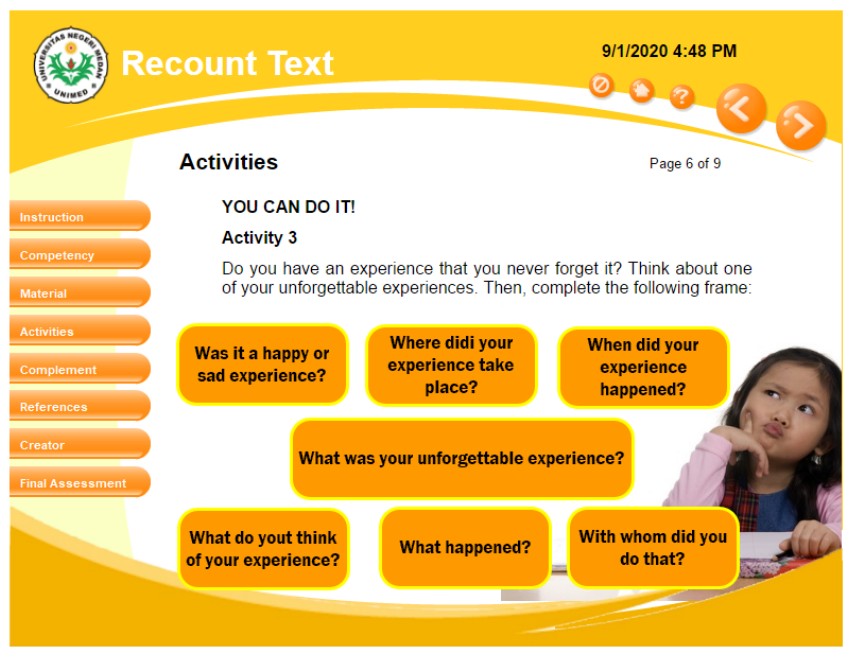

Figure 4.11. The Activity of writing the students' recount text based on personal unforgettable experiences in the past

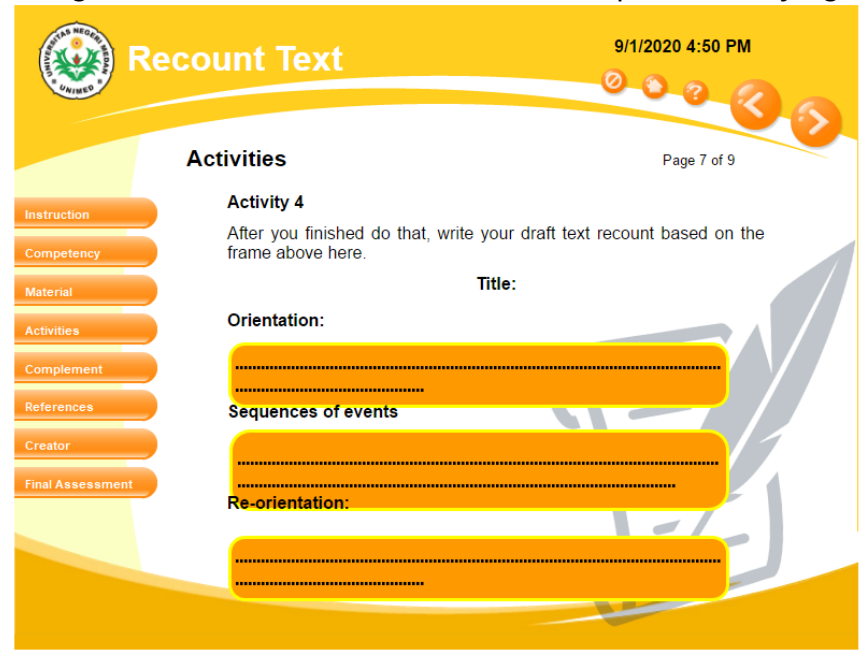

Figure 4.12. Draft of writing recount text

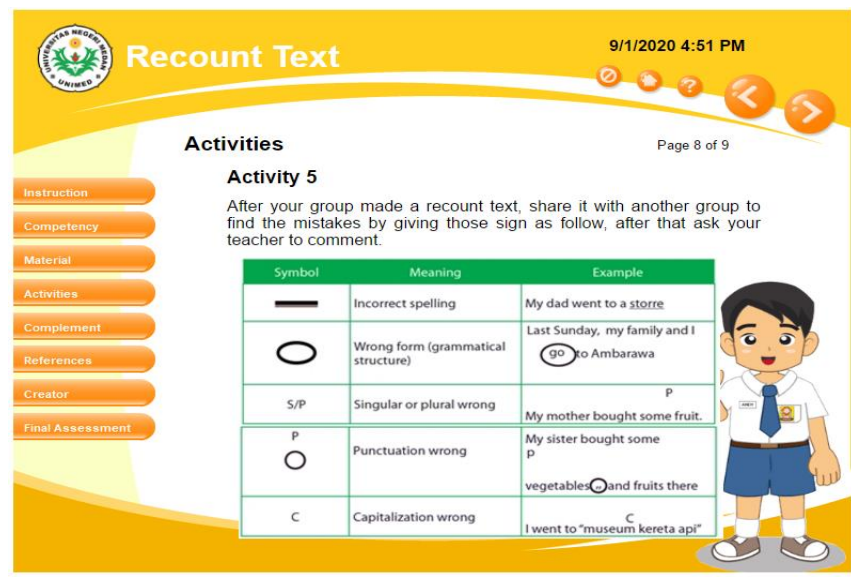

Figure 4.13. Students' Written Assessment 


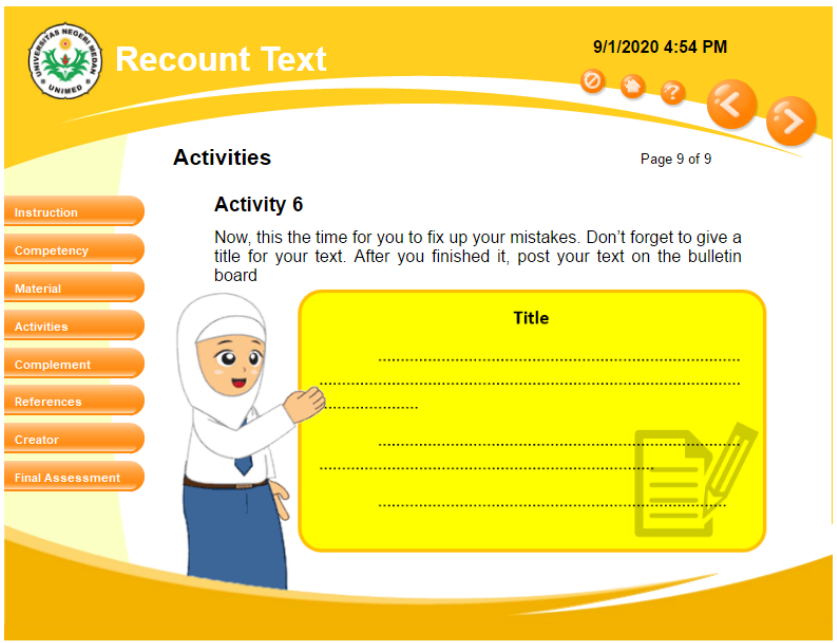

Figure 4.14. Students' Final Activity

In the closing activity, the teacher helped the students to make a summary/conclusion of the lesson reflection. After that the teacher provided the feedback of the learning process and results conducted. Then, the students provide a reflection on what they learned in 10 Minutes.

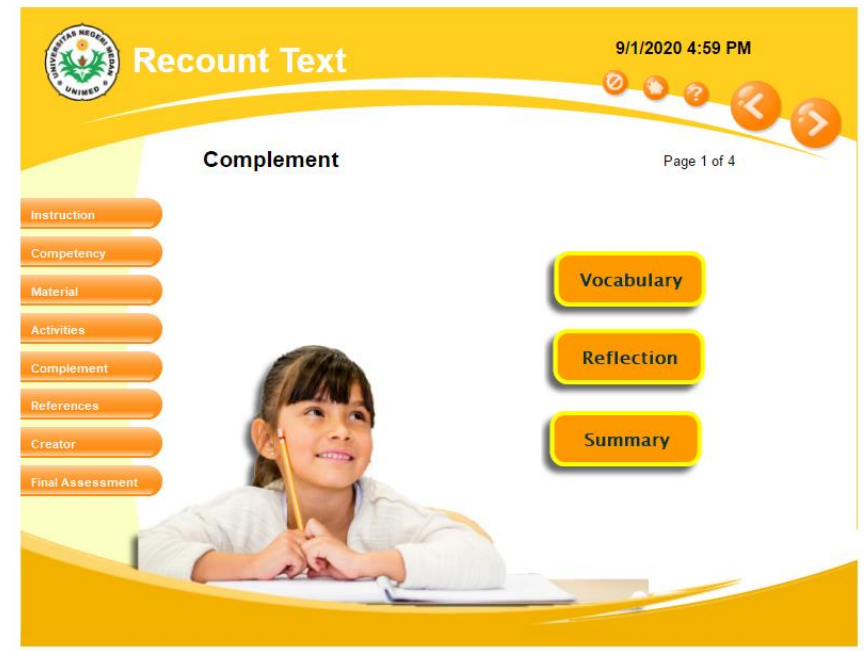

Figure 4.15. the Front View of Complement

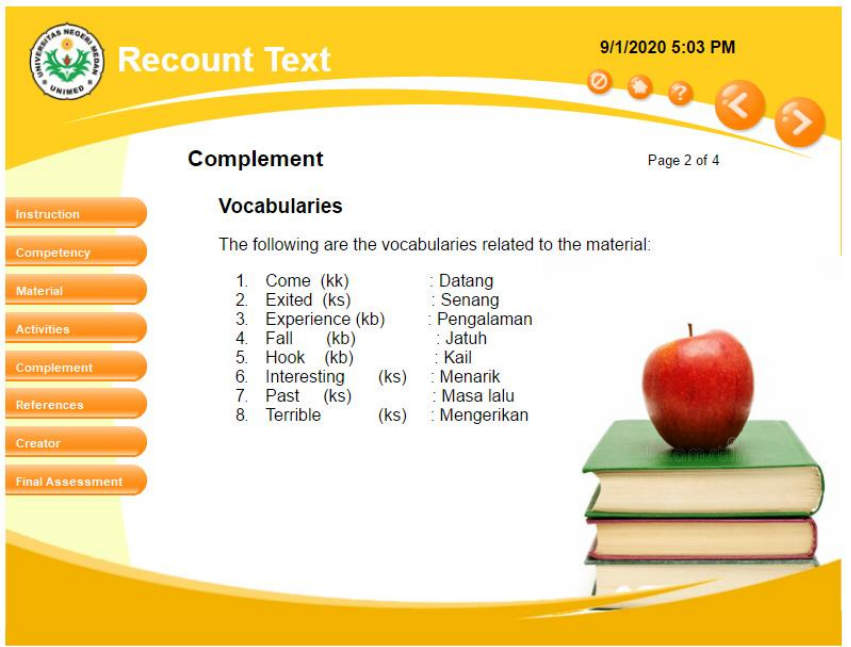

Figure 4.16. Vocabularies of Complement 


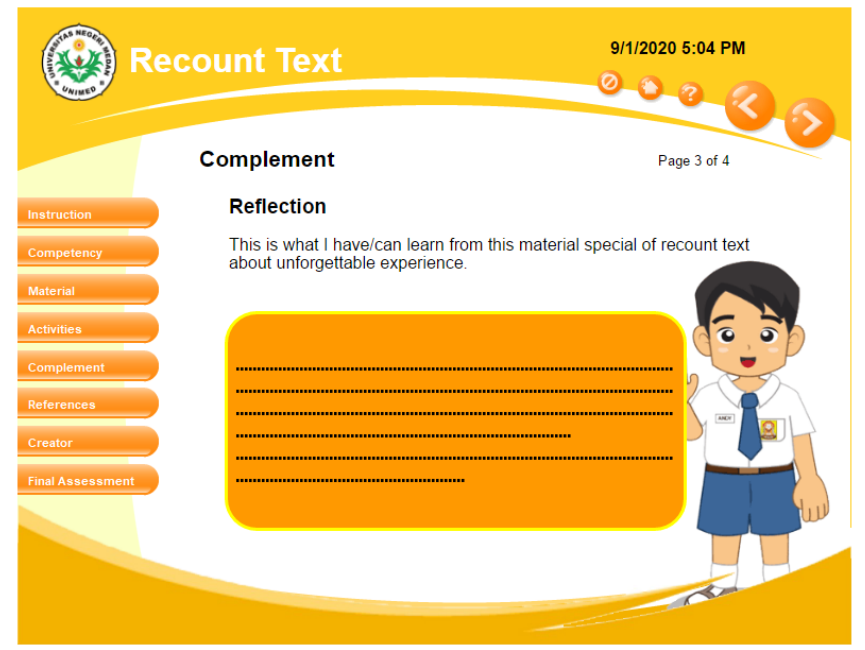

Figure 4.17. Reflection of Complement

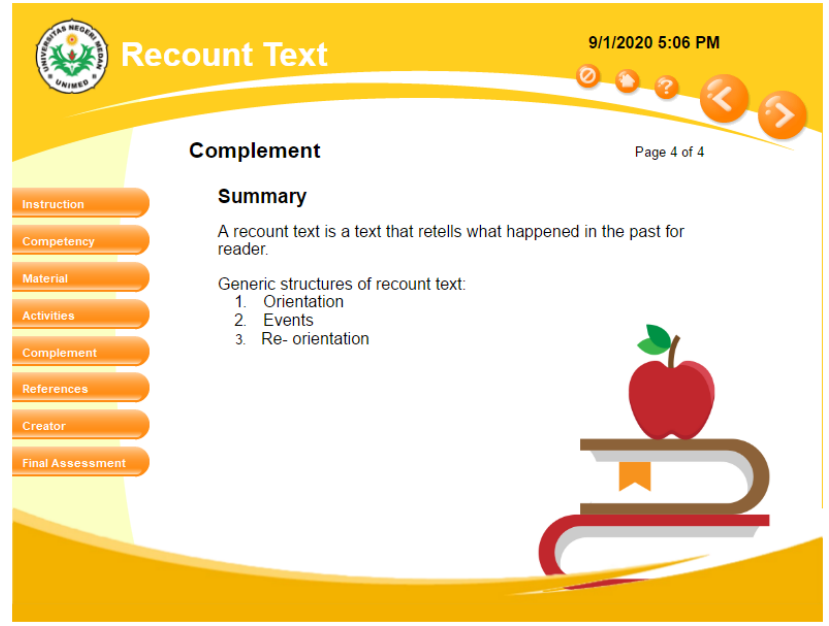

Figure 4.18. Summary of Complement

Furthermore, there was an evaluation test, comprising multiple choices in evaluating the students' comprehension in mastering the material.

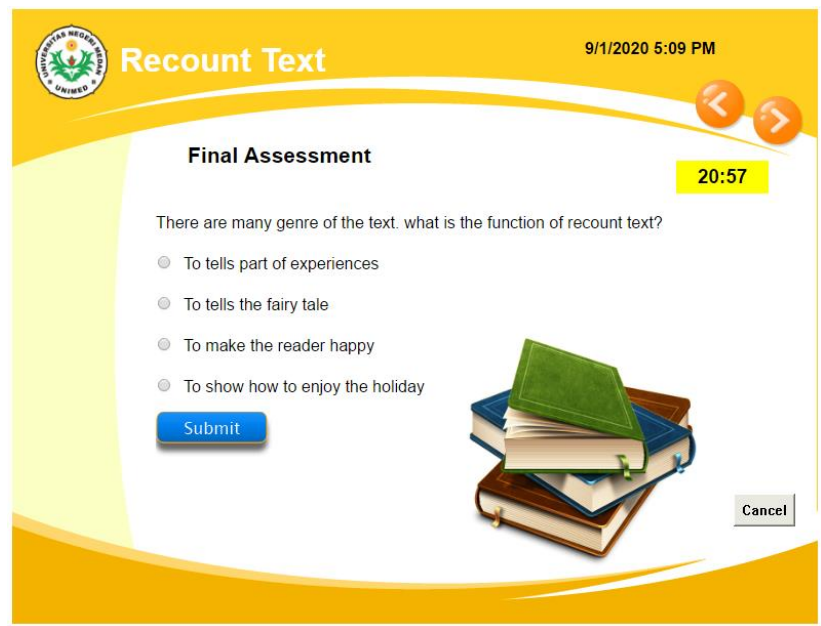

Figure 4.19. Final Assessment (Multiple Choice) 


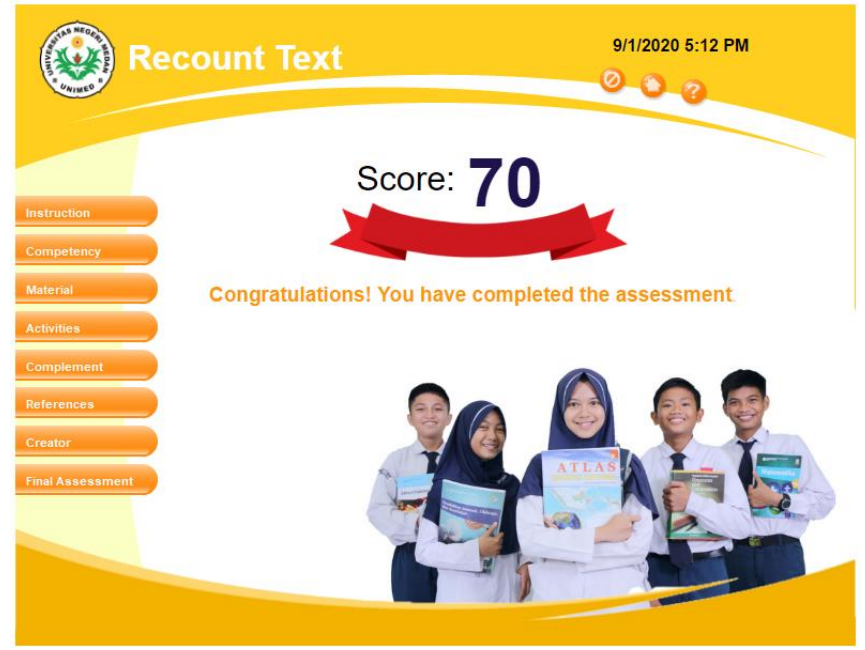

Figure 4.20. Grading of Evaluation Test

Furthermore, this media was validated by some experts. They were a lecturer of English and Literature department and two teachers at SMP N 35 Medan. Based on the result of validation, it was obtained that a number of validation percentage was 95\% categorized excellent. After the Lectora Inspire was validated and revised, the media was implemented to the students on writing genre for the students at SMP N 35 Medan. Its result showed that there was an improvement on students' writing skill related to genres which meant that the media was effective media in learning Writing at SMP N 35 Medan. It could be known by analyzing the results of students' questionnaires toward the Lectora Inspire use in mastering writing skill.

\section{Conclusion}

Based on the results of the study, it was known that there were several difficulties faced by students in achieving the objectives of the teaching and learning process itself due to manual learning media. The learning media needed at SMP Negeri 35 Medan was a medium which could attract the students' attention in writing genre.

On the other hand, teachers also had difficulty getting students to understand the material being taught due to the lack of learning media and lack of knowledge in developing learning media. From the interviews conducted, researchers could identify that teachers also needed learning media which could make the learning process more effective and efficient. Besides, learning media had to be related to daily life and attract students' attention in mastering writing skill. Furthermore, based on questionnaire results given to the students, it was known that the students wanted the combination of interesting, motivates in learning, and color combination in interactive learning media.

Therefore, Lectora Inspire was developed to improve students' writing at SMP N 35 Medan. The interactive learning multimedia was developed by the researcher by doing several steps. The steps consisted of preparing the material, designing the story board, choosing the layout, background, sound, video, and animations.

Furthermore, the media was validated by some experts namely a lecturer and two English teachers at SMP N 35 Medan. The average percentage of validation result was $95 \%$ categorized excellent. In addition, the media also could improve the students' ability in writing skill related to genres. It meant that the media was effective media in mastering writing skill at SMP N 35 Medan.

\section{References}

[1] Arsyad, A. 2013. Media Pembelajaran. Jakarta: PT Grafindo Persada.

[2] Dewita, Tiara. 2015. Pengembangan Media Pembelajaran Menulis Pusisi Berbasis Lectora Inspire dengan Metode Self Directed Learning untuk Siswa kelas VII SMP Negeri 3 Jetis Bantul. Fakultas Bahasa dan Seni. Universitas Negeri Yogakarta. Yogyakarta.

[3] Dirgayasa, I. W. (2016). College Academic Writing a Genre- Based Perspective.Jakarta

[4] Faruk, A. (2014). Development of Interactive Learning Media Based Lectora linspire. Sriwijaya University.

[5] Gall, M. D., Gall, J. P., \& Borg, W. R. (2003). Education research: An introduction, (7 th Ed.). Boston: Allyn \& Bacon.

[6] H. Dalman, (2014). Keterampilan Menulis . Jakarta: PT. Raja Grafindo Persada.

[7] Harmer, J. (2004). How to Teach Writing. New York: Longman. 
[8] Haryanti, A. P. (2016). Developing Writing Materials for the Students of the Eighth Grade of SMP N 3 Tempel. English Language Teaching Journal, 5(3).

[9] Komalasari, Kokom (2013). Pembelajaran Kontekstual: Konxep dan Aplikasi. Bandung: PT Refika Aditama

[10] Mudinillah, A. (2019). Pemanfaatan Aplikasi Lectora Inspire Sebagai Media Pembelajaran Interaktif Pada Pelajaran Bahasa Arab. Jurnal Penelitian IPTEKS, 4(2), 248-258.

[11] Mulyana, S. (2019). Unit Pembelajaran Program Pengembangan Keprofesian (PKBI) melalui Peningkatan Kompetensi Pembelajaran (PKP) berbasis Zonasi_Mata Pelajaran Bahasa Inggris Teks Recount SMP. Direktorat Jenderal Guru dan Tenaga Kependidikan KEENDIKBUD: Jakarta.

[12] Norma, D. (2017). Media Pembelajaran Interaktif Lectora Inspire sebagai Inovasi Pembelajaran. Universitas Muhammadiyah Magelang.

[13] Setyosari, H. P. (2016). Metode penelitian pendidikan \& pengembangan. Prenada Media.

[14] Shams, A., Khanam, A., \& Imtiaz, S. (2016). The impact of audio-visual aids and graphic organizers on the writing skills of ESL learners at AMU+ 2 girls. Global Journal of Interdisciplinary Social Sciences, 5(5), 15-36.

[15] Sitohang, I., \& Purnawarman, P. (2015). THE EFFECTIVENESS OF JIGSAW STRATEGY TO IMPROVE STUDENTS'SKILL IN WRITING A RECOUNT TEXT. English Review: Journal of English Education, 3(2), 183-189.

[16] Sugiono, S. (2016). Metode Penelitian Kuantitatif, Kualitatif, dan R \& D. Bandung: Alfabeta.

[17] Suharto, G. (2005). Penilaian Hasil Belajar Bahasa Inggris. Yogyakarta: Universitas Negeri Yogyakarta.

[18] Supardi, S., Ertikanto, C., \& Manurung, P. (2017). Student Worksheet Static Fluid Material Based on Scientific Approach Using Giuded Inquiry Model. In International Journal of Science and Applied Science: Conference Series (Vol. 2, No. 1, pp. 368-380).

[19] Suyadi. (2017). An Analysis of Students' Writing Skills in Recount Text at the Eight Grade Students of SMP Negeri 2 Kota Jambi. Journal of English Language Teaching, 1(1).

[20] Trianto. (2010). Mendesain Model Pembelajaran Inovatif-Progresif. Jakarta : PT. Kencana.

[21] Zaim. 2017. Implementing Scientific Approach to Teach English at Senior High School in Indonesia. Asian Social Science, 13(2)

[22] Zakky. (2020). Pengertian Pembelajaran Menurut Para Ahli dan Secara Umum [Lengkap]. Diakses dari https://www.zonareferensi.com/pengertian-pembelajaran/ pada 12 Mei 2020. 